\title{
Spatial and temporal distribution of mercury and methylmercury in bivalves from the French coastline
}

\author{
Briant Nicolas ${ }^{1,{ }^{*}}$, Chouvelon Tiphaine ${ }^{1}$, Martinez Laura ${ }^{1}$, Brach-Papa Christophe ${ }^{1}$, \\ Chiffoleau Jean-Francois ${ }^{1}$, Savoye Nicolas ${ }^{2}$, Sonke Jeroen ${ }^{3}$, Knoery Joel ${ }^{1}$
}

${ }^{1}$ Laboratoire de Biogéochimie des Contaminants Métalliques, Ifremer, Centre Atlantique, F-44311, Nantes Cedex 3, France

${ }^{2}$ Université Bordeaux, EPOC, UMR 5805, F-33400 Talence, France

${ }^{3}$ Observatoire Midi-Pyrénées, Laboratoire Géosciences Environnement Toulouse, CNRS/IRD/université Paul-Sabatier, 14, avenue Edouard-Belin, F-31400 Toulouse, France

* Corresponding author : Nicolas Briand

\begin{abstract}
:
Marine mercury $(\mathrm{Hg})$ concentrations have been monitored in the French coastline for the last half a century using bivalves. The analyses presented in this study concerned 192 samples of bivalves (mussels: Mytilus edulis and Mytilus galloprovincialis and oysters: Crassostrea gigas and Isognomon alatus) from 77 sampling stations along the French coast and in the French Antilles sea. The goals of this study were to assess $\mathrm{MeHg}$ levels in various common bivalves from French coastline, and to identify possible geographic, taxonomic or temporal variations of concentrations. We show that the evolution of methylmercury $(\mathrm{MeHg})$ concentrations covary with total mercury $(\mathrm{HgT})$ concentrations. Moreover, in most of the study sites, HgT concentrations have not decreased since 1987, despite regulations to decrease or ban mercury used for anthropic activities.
\end{abstract}

\section{Highlights}

$\mathrm{Hg}$ concentrations did not decrease over the last 30 years. MeHg concentrations increase with total mercury concentrations. Time series of biological samples enable to quantify the evolution of pollutant levels in the coastal environment.

Keywords : Mercury, Methylmercury, France, Bivalves, Speciation 
Mercury $(\mathrm{Hg})$ is a non essential and highly toxic trace element for which the biogeochemical cycle is perturbed by anthropic inputs. Studies show that atmospheric depositions are the primary sources of mercury pollution in aquatic systems (Semkin, Mierle, et Neureuther 2005), and that anthropogenic activities continue to emit significant amounts of mercury into the air (Wu et al. 2006; Chen et al. 2013). Mercury levels have risen in the environment and have tripled in surface ocean waters since the industrial revolution (Lamborg et al. 2014). The toxicity of inorganic mercury causes renal lesions, neurotoxicity and cardiovascular disorders. Moreover the organic form of mercury (Methylmercury, $\mathrm{MeHg}$ ) is the most toxic species for humans, causing serious central nervous system dysfunctions (Harada, 1995). Recently, the UNEP Governing Council drew up the Minamata Convention on Mercury (2013). This multilateral environmental agreement addresses the adverse effects of mercury through practical actions to protect human health and the environment from anthropogenic emissions and releases of mercury and mercury compounds. Monitoring by the French Mussel Watch program (RNO-ROCCH) can be useful to determine the effectiveness of these regulations. Indeed bivalves can accumulate pollutants in their tissues at elevated levels related to pollutant availability in the marine environment. This, they have been used as biomonitors of the coastal environment («OSPAR Convention» 1992). As such, The French National Monitoring Network RNO-ROCCH (Observation Network of chemical contamination of the marine environment) aims to track chemical contaminants on the national coastline (Claisse 1989). Because not one single species of bivalve is common to all coastal regions, three species are collected to obtain national coverage.

The purposes of this study were to assess $\mathrm{MeHg}$ values in various common bivalves from French coastline and to identify possible geographic, taxonomic (intercomparison between species) or temporal variations of concentrations. We measured the MeHg concentrations of soft tissues in mussels (Mytilus edulis, Mytilus galloprovincialis) and oysters (Crassostrea gigas, Isognomon alatus). They were collected during the first trimester of years between 1987 and 2014 at various sites along the French shoreline and in French Caribbean islands. The objective was (i) to assess the spatial variation by determining MeHg concentrations of bivalves during one year at the same trimester around the French coasts (ii) to evaluate interspecific differences and linkage to local ecosystem characteristics, and (iii) to follow the 
evolution of $\mathrm{MeHg}$ concentrations over 30 years in sites of interest to check an eventual global tendency.

This study presents 192 samples of bivalves (mussels: Mytilus edulis and Mytilus galloprovincialis and oysters: Crassostrea gigas and Isognomon alatus) from 77 sampling stations along the French coast and in French Caribbean (Fig. 1). The spatial distribution study was realized on 75 sites of the metropolitan coast line with bivalves collected during the first semester (February and March) of 2014, to avoid seasonal variations of bivalves' tissues. The choice of the first semester was done by the ROCCH team because it is the period when the biological conditions of bivalves are the most stable. Two sites of French Caribbean islands were also sampled from the first semester of 2006 using local oyster species Isognomon alatus. Finally, the temporal variations were studied at 11. One "mussel" sample represents fifty individual mussels (35-65 $\mathrm{mm}$ in shell length) and one "oyster" sample represents 10 cultivated bivalves between two and three years old. Bivalves have been collected in an identical modus operandi every year since 1979 within the framework of the French mussel watch program (RNO-ROCCH). Briefly, they are cleaned of epibiota and depurated for $24 \mathrm{~h}$ in a PE tank containing decanted water from the sampling site, in order to eliminate faeces and pseudofaeces. The soft tissue is removed from the shell, homogenized with a stainless steel blade, and freeze-dried as recommended by the guidelines of the OSPAR Convention. The method is fully described in Claisse (1989). The MeHg determination was performed according to Azemard et Vassileva (2015) using a liquid-liquid extractions. Analyses were carried out using an advanced mercury analyzer (AMA-254, Altech Czech Republic). After solubilization of the stored lyophilized tissues in $\mathrm{HCl}(3 \mathrm{~N})$, toluene is added and both phases homogenized. After centrifugation, a fraction of the upper organic phase with extracted $\mathrm{MeHg}$ is transferred to a second tube containing the same volume of $2 \mathrm{mM}$ sodium thiosulfate solution. This second tube was vigorously shaken and centrifuged. An aliquot $(400 \mu \mathrm{L})$ of the lower phase, which contains the back-extracted organic mercury, was directly analyzed with the AMA. Precision was determined by comparing the analyzed concentrations of total $\mathrm{Hg}(\mathrm{HgT})\left(61.00 \pm 3.60 \mu \mathrm{g} . \mathrm{kg}^{-1}\right.$ d.w $)$ and $\mathrm{MeHg}\left(28.09 \pm 0.31 \mu \mathrm{g} . \mathrm{kg}^{-1} \mathrm{~d} . \mathrm{w}\right)$ with the certified values of the CRM-NIST-2976. For MeHg, our CRM mean value $(n=36)$ is $27.83 \pm$ $0.22 \mu \mathrm{g} . \mathrm{kg}^{-1} \mathrm{~d}$.w. The detection limit of the AMA-254 was $0.05 \mathrm{ng}$ of $\mathrm{Hg}$. HgT was directly analyzed by the AMA from the lyophilized samples. Statistical analyses were done using the free software "R". Because the data were not normally distributed, nonparametrical statistical approaches were utilized for data comparison. 
Concentrations of $\mathrm{HgT}$ and $\mathrm{MeHg}$ in oyster and mussel tissues are presented in Table I. Concentrations of $\mathrm{HgT}$ and $\mathrm{MeHg}$ of the French coast line in 2014 varied between 60 and $670 \mu \mathrm{g} . \mathrm{kg}^{-1}$ d.w and 9 to $145 \mu \mathrm{g} . \mathrm{kg}^{-1}$ d.w respectively. MeHg values were within the range of values reported previously in other studies (Odžak et al. 2000; Claisse et al. 2001; Apeti, Lauenstein, et Evans 2012). Comparisons of values between species are done regarding results from statistical tests. For $\mathrm{HgT}$ and for $\mathrm{MeHg}$ level the sole interspecific differences were observed between C.gigas and Mytilus spp. Isognomon alatus values are too few to be statistically used. After combining all sampling sites, mean concentration of $\mathrm{HgT}$ are similar for both mussels species (Wilcoxon test, $p$ value $=0.31$ ). Mean concentration is different for oysters $C$.gigas (Wilcoxon test, $p$ value $<0.05$ ) with both mussels species. HgT concentrations for $C$.gigas are slightly higher than those of Mytilus spp $(240 \mu \mathrm{g} . \mathrm{kg}-1 \mathrm{~d}$.w versus $\sim 174 \mu \mathrm{g} . \mathrm{kg}-1$ d.w respectively). Same tests for MeHg concentrations show no difference between species (Wilcoxon test, $p$ value $>0.05$ ). Levels of $\mathrm{HgT}$ and $\mathrm{MeHg}$ in bivalves revealed a wide variability in the distribution of mercury across the monitoring area. Statistical analyses of $\mathrm{HgT}$ or MeHg levels did not permit to differentiate specific ecosystem specificities such as estuarine or bay or open coast or lagoon.

Nevertheless different "hotspots" could be observed for $\mathrm{HgT}$ and $\mathrm{MeHg}$. We defined hotspots as top $10 \%$ of the concentration distribution. They have levels above $320 \mu \mathrm{g} . \mathrm{kg}-1 \mathrm{~d} . \mathrm{w}$ for $\mathrm{HgT}$ and above $103 \mu \mathrm{g} . \mathrm{kg}-1 \mathrm{~d} . \mathrm{w}$ for MeHg. There is evidence of the influence of mercury point sources near several estuaries. Elevated concentrations of $\mathrm{HgT}$ are found in bivalves of Seine Bay, near the Loire estuary and in the Gironde estuary (320, 360, $380 \mu \mathrm{g} . \mathrm{kg}-1 \mathrm{~d} . \mathrm{w}$ respectively, Fig.2). For some estuaries such as the Seine historical industrial activity could explain the quite high concentration of $\mathrm{Hg}$ (Foucher 2002 ; Laurier et al. 2003). As described by Claisse et al. (2001), the main contamination spot is Toulon-Lazaret site (\#71, Fig.1) with concentrations up to $670 \mu \mathrm{g} . \mathrm{kg}-1 \mathrm{~d} . \mathrm{w}$ of $\mathrm{HgT}$ and $132 \mu \mathrm{g} . \mathrm{kg}-1 \mathrm{~d} . \mathrm{w}$ of MeHg. This bay is well known as a highly contaminated site, most probably linked to military activities of this harbor (Tessier et al. 2011). Moreover, Tessier et al. (2011) have identified mercury as the most problematic contaminant of this site, with wide dispersion throughout the whole bay.

Except for Toulon-Lazaret which is highly contaminated, MeHg "hotspots" are quite unusual from our knowledge. In the English Channel coast at Le Moulard site (\#13), MeHg concentration is $135 \mu \mathrm{g} . \mathrm{kg}-1 \mathrm{~d}$.w, which represents $48 \%$ of $\mathrm{HgT}$. The other hotspot is 
Noirmoutier site (\#39) at the south of the Loire River estuary. The levels are $\sim 145 \mu \mathrm{g} . \mathrm{kg}-1 \mathrm{~d} . \mathrm{w}$ which represent $40 \%$ of the $\mathrm{HgT}$ concentration. For these two sites, we have not observed an obvious source of this contamination, although local over-productivity of $\mathrm{MeHg}$ by biotic or abiotic processes in nearly salt marshes might be an explanation for these results (Mitchell and Gilmour. 2008).

Methylmercury levels in bivalve soft tissues varied greatly along the French coast, yet no significant differences were found between organisms (Table I). The proportion of MeHg to $\mathrm{HgT}$ ranged from 13.1 to $54.1 \%$, with a median of $30.4 \%$. The highest percentages corresponded to the sites Varengeville (\#5) and Le Moulard (\#13) in the English Channel coast, Brittany sites Pointe er Fosse (\#34) and Le Croisic (\#36) for the Atlantic coast, and the Prévost lagoon (\#65) on the Mediterranean coast. Ratios ranged over $48 \%$ and up to $54.1 \%$ at Varengeville. This latter particular site was already described with high mercury and methylmercury concentrations coming from the karstic watershed of the Caux region (Laurier et al. 2007). Inputs from groundwater with high $\mathrm{MeHg}$ concentrations were also shown by Ganguli et al. 2012 in a coastal lagoon system. In this study, the $\mathrm{MeHg} / \mathrm{HgT}$ ratios are lower than previous studies on the French coast. Claisse et al. (2001) reported ratio of about 43\%, Mikac et al. (1996) reported ratio about 40\% in mussels from the Kska Estuary in Croatia. However Apeti et al, 2012 reported a median ratio of $34 \%$ in oysters of the northern Gulf of Mexico. Generally, MeHg concentrations increase with $\mathrm{HgT}$ in the environment (Fig 2c). How does $\mathrm{MeHg}$ levels depend on $\mathrm{Hg}$ concentrations?

Total mercury concentrations are still high in many point of the French coast despite the decrease of $\mathrm{Hg}$ usage for various anthropic activities (phase out of chlor-alkali plants, mercury batteries or medical thermometers, etc). Indeed the mercury concentrations in a wide variety of ecosystems and geographic localization do not show a significant decrease over the last 30 years (Fig. 3).

For the three studied organisms, $\mathrm{HgT}$ concentrations as well as $\mathrm{MeHg}$ concentrations did not decrease since 1987. Moreover in the case of Villerville (\#9) and Toulon-Lazaret a slight increase could be observed between 1987 and 2014. As explained before, Toulon Lazaret is a highly contaminated site and the increase of concentrations could be explained by local remobilization of dredged sediment from the inner bay. In the case of Villerville, the Seine River could be bringing to that site more $\mathrm{Hg}$ year after year. Although, the concentration patterns of $\mathrm{MeHg}$ and $\mathrm{HgT}$ look similar, the fraction of $\mathrm{MeHg}$ fluctuates independently 
between 20 and $50 \%$. These observations suggest that $\mathrm{HgT}$ is not the limiting factor in the environment for the production of $\mathrm{MeHg}$, and that other factors like bacterial methylation activity, organic matter quality and quantities or sulfate concentrations are more limiting (Choi et Bartha 1994; Heyes, Miller, et Mason 2004). However in a context of global change and an increase of ocean temperatures, one or more of these factors may become less limiting, and potentially raising future $\mathrm{MeHg}$ concentrations at the base of the food web.

This study showed that long time series of biological samples are crucial to follow the evolution of pollutant levels. Moreover we identified that in the majority of the study sites HgT concentrations have not decreased significantly since 1987, despite national, European and international regulation to decrease mercury used in anthropic activities, and despite the decrease in Hg atmospheric deposition since the 1990's (Zhang et al. 2016). Since oceanic and coastal ecosystems are complex with respect to $\mathrm{Hg}$ behavior and fate, a lag could occur between atmospheric deposition and ocean concentrations (Sunderland et Mason 2007). Bivalves represent the base of the trophic food web, and $\mathrm{MeHg}$ concentrations ranged from 9 to $145 \mu \mathrm{g} \cdot \mathrm{kg}^{-1}$. With the risk of global change -mediated changes of $\mathrm{MeHg}$ levels, the origin of mercury introduced into coastal food web needs to be determined, and parameters like $\delta^{15} \mathrm{~N}$, $\delta^{13} \mathrm{C}$ and $\mathrm{Hg}$ stable isotopes could be useful.

\section{Acknowledgement}

We gratefully acknowledge funding of this study obtained from IFREMER, Région Pays de la Loire (PolluSols), and the INSU program EC2CO/DRIL. 


\section{Captions}

Table I: Sample table for the 2014 mercury speciation map. Concentrations and summary of site characteristics.

Fig 1: Geographic location of the sampling sites.

Fig 2: a) Spatial distribution of the mercury in the bivalves. Blue dots are the exact locations and symbol shapes and colors identify the type of organisms. b) Spatial distribution of methylmercury in bivalves. c) Correlations of methylmercury ( $\mathrm{MeHg}$ ) with total mercury (HgT) for C.gigas and Mytilus spp for metropolitan France in 2014. Geographic location of the sampling sites.

Fig 3: Concentrations of $\mathrm{HgT}$ (open diamonds) and $\mathrm{MeHg}$ (black dots) at eleven sites from metropolitan France, from 1987 to 2014 with a step 3 years time. Also shown are the fitted curves from a logistic Generalised Linear Model. 


\section{References:}

Apeti, D. A., G. G. Lauenstein, et D. W. Evans. 2012. «Recent status of total mercury and methyl mercury in the coastal waters of the northern Gulf of Mexico using oysters and sediments from NOAA's mussel watch program ». Marine pollution bulletin 64 (11): 2399- 2408.

Azemard, S, et E Vassileva. 2015. « Determination of methylmercury in marine biota samples with advanced mercury analyzer: Method validation ». Food chemistry 176: 367- 75.

Chen, L, M Liu, R Fan, S Ma, Z Xu, M Ren, et Q He. 2013. "Mercury speciation and emission from municipal solid waste incinerators in the Pearl River Delta, South China ». Science of The Total Environment 447 (mars): 396- 402.

Choi, S.-C., et R. Bartha. 1994. «Environmental factors affecting mercury methylation in estuarine sediments ». Bulletin of Environmental Contamination and Toxicology 53 (6): 805- 12.

Claisse, D. 1989. « Chemical contamination of French coasts: the results of a ten years mussel watch ». Marine pollution bulletin 20 (10): 523- 28.

Claisse, D., D. Cossa, J. Bretaudeau-Sanjuan, G. Touchard, et B. Bombled. 2001. «Methylmercury in molluscs along the French coast». Marine pollution bulletin 42 (4): 329- 32.

Foucher, D. 2002. "Geochemistry of mercury in estuarine and coastal sediments: case studies in the Seine estuary (France) and the Kastela bay (Croatia) ». Ph. D. thesis. Univ. Lille 1, France.

Ganguli P. M., C. H. Conaway, P. W. Swarzenski, J. A. Izbicki and A. R. Flegal. 2012 «Mercury Speciation and Transport via Submarine Groundwater Discharge at a Southern California Coastal Lagoon System ». Environmental Science \& Technology, $46,1480-88$

Harada, M. 1995. «Minamata Disease: Methylmercury Poisoning in Japan Caused by Environmental Pollution ». Critical Reviews in Toxicology 25 (1): 1- 24.

Heyes, A, C Miller, et R P Mason. 2004. «Mercury and methylmercury in Hudson River sediment: impact of tidal resuspension on partitioning and methylation ». Marine Chemistry 90 (1): 75- 89.

Lamborg, C H., C R. Hammerschmidt, K L. Bowman, G J. Swarr, K M. Munson, D C. Ohnemus, P J. Lam, L-E Heimbürger, M J. A. Rijkenberg, et M A. Saito. 2014. « A Global Ocean Inventory of Anthropogenic Mercury Based on Water Column Measurements ». Nature 512 (7512): 65- 68. doi:10.1038/nature13563.

Laurier, F. J. G., D Cossa, J. L Gonzalez, E Breviere et G Sarazin. 2003. « Mercury transformations and exchanges in a high turbidity estuary: The role of organic matter and amorphous oxyhydroxides ». Geochimica et Cosmochimica Acta 67 (18): 3329- 45

Laurier, F. J. G., D Cossa, C Beucher, et E Breviere. 2007. "Reprint of "The impact of groundwater discharges on mercury partitioning, speciation and bioavailability to mussels in a coastal zone" ". Marine Chemistry 106 (1): 352- 64.

Mikac, N, Ž Kwokal, D Martinčić, et M Branica. 1996. «Uptake of mercury species by transplanted mussels Mytilus galloprovincialis under estuarine conditions (Krka river estuary) ». Science of the total environment 184 (3): 173- 82.

Mitchell, C. P. J., et C. C. Gilmour 2008. Methylmercury production in a Chesapeake Bay salt marsh, Journal of Geophysical Research, 113

Odžak, N, T Zvonarić, Z K Gašpić, M Horvat, et A Barić. 2000. «Biomonitoring of mercury in the Kaštela Bay using transplanted mussels ». Science of the total environment 261 (1): 61- 68 . 
OSPAR Convention-1992. OSPAR Commission. http://www.ospar.org/convention/text.

Semkin, R G., G Mierle, et R J. Neureuther. 2005. « Hydrochemistry and Mercury Cycling in a High Arctic Watershed». The Science of the Total Environment 342 (1-3): 199- 221.

Sunderland, E. M., et R. P. Mason. 2007. «Human impacts on open ocean mercury concentrations ». Global Biogeochemical Cycles 21 (4).

Tessier, E, C Garnier, J-U Mullot, V Lenoble, M Arnaud, M Raynaud, et S Mounier. 2011. "Study of the spatial and historical distribution of sediment inorganic contamination in the Toulon bay (France) ». Marine pollution bulletin 62 (10): 2075- 86.

Wu, Y, S Wang, D G Streets, J Hao, M Chan, et J Jiang. 2006. « Trends in Anthropogenic Mercury Emissions in China from 1995 to 2003 ». Environmental Science \& Technology 40 (17): 5312- 18.

Zhang, Y, D. J. Jacob, H. M. Horowitz, L. Chen, H. M, Amos, D. P. Krabbenhoft, F. Slemr, V. L. St Louis et E. M. Sunderland. 2016. "Observed decrease in atmospheric mercury explained by global decline in anthropogenic emissions ». Proceeding of the National Academy of Science of United States of America 113 (3): 526-31. 


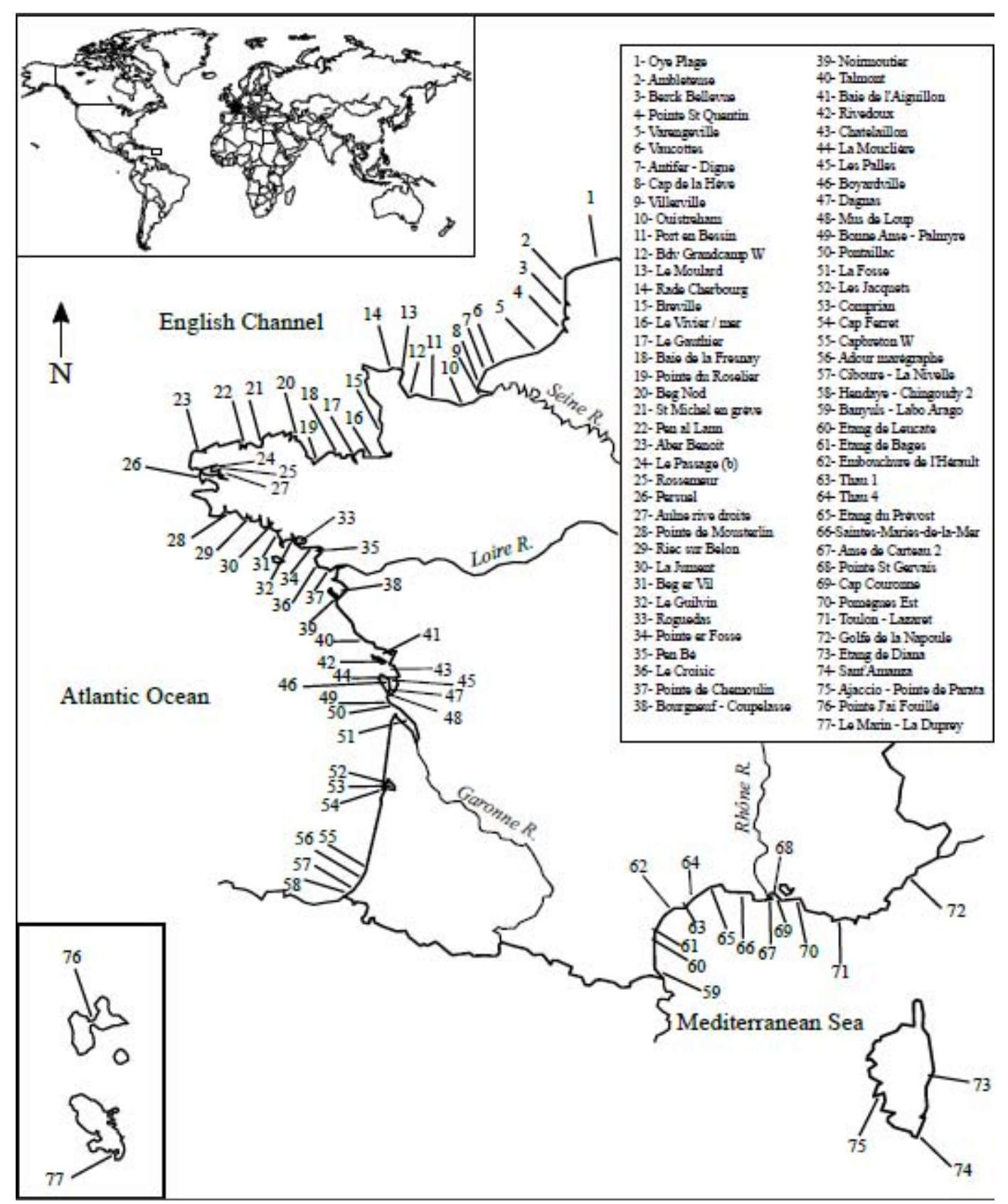


a)
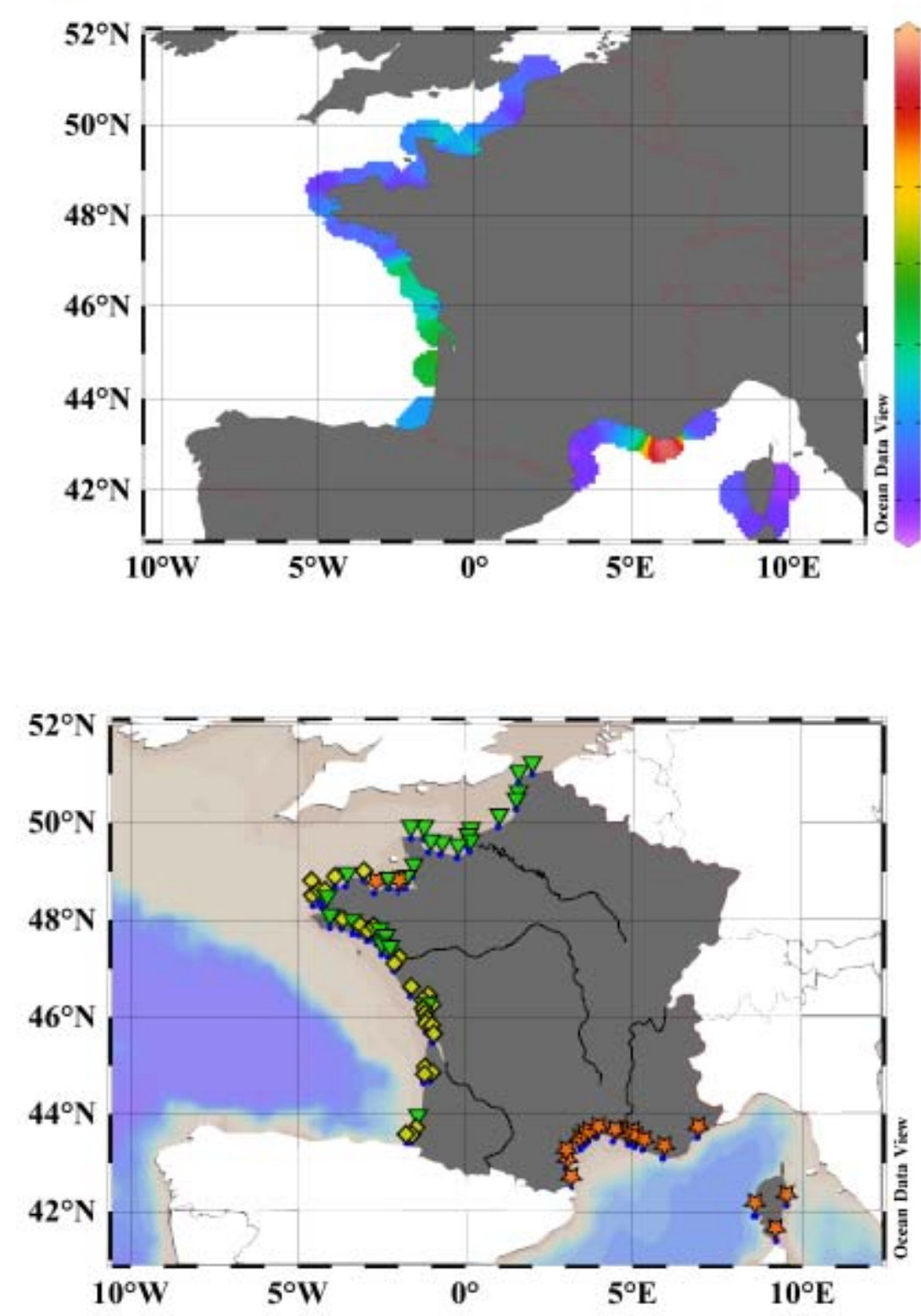

b)

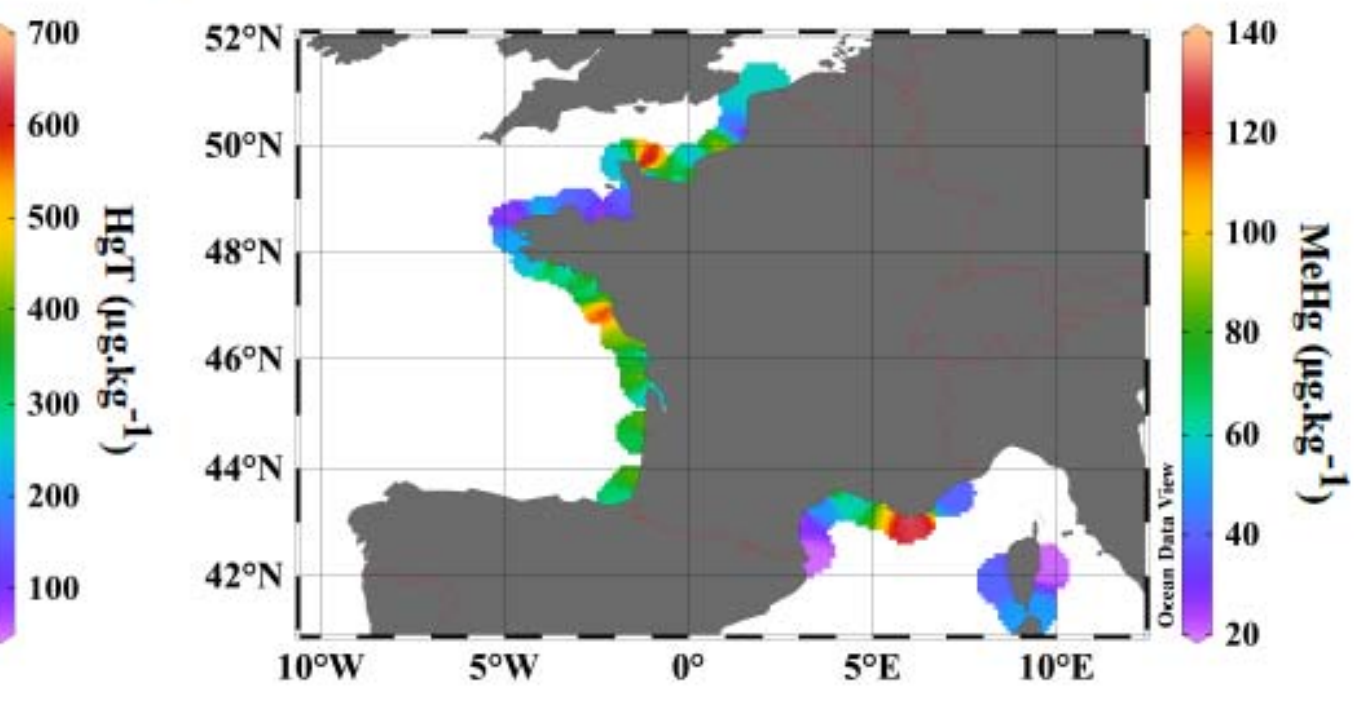

c)

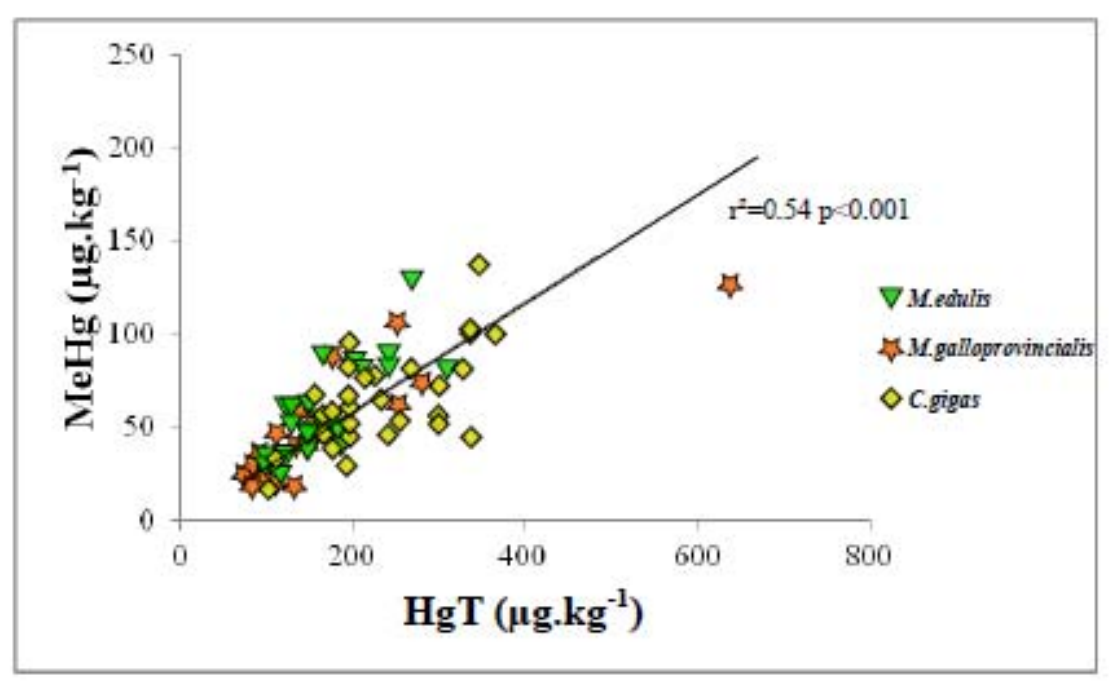




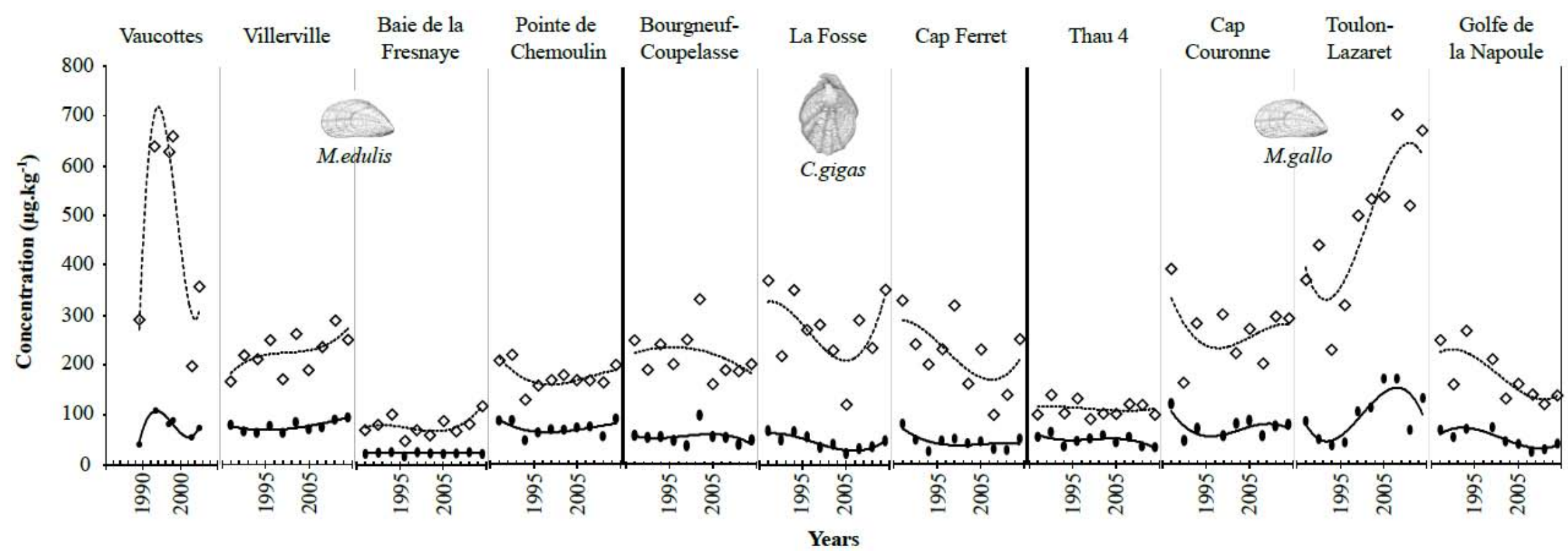




\begin{tabular}{|c|c|c|c|c|c|c|c|c|}
\hline Site & Specie & $\begin{array}{c}\text { Sea/Ocean } \\
\text { location }\end{array}$ & Ecosystem & Year & $\begin{array}{c}\text { HgT } \\
\left(\mu g . \mathrm{kg}^{-1} \mathrm{dw}\right)\end{array}$ & $\begin{array}{c}\mathrm{MeHg} \\
\left(\mu \mathrm{g} \cdot \mathrm{kg}^{-1} \mathrm{dw}\right)\end{array}$ & $\underset{\left(\mu \mathrm{g} \cdot \mathrm{kg}^{-1} \mathrm{dw}\right)}{\text { IHg }}$ & $\begin{array}{c}\text { ratio } \\
(\%)\end{array}$ \\
\hline Oye plage & M. edulis & English Channel & Coast & 2014 & 150 & 64 & 86 & 42.5 \\
\hline Ambleteuse & M. edulis & English Channel & Coast & 2014 & 180 & 56 & 124 & 30.9 \\
\hline Berck Bellevue & M. edulis & English Channel & Coast & 2014 & 150 & 49 & 101 & 32.5 \\
\hline Pointe de St Quentin & M. edulis & English Channel & Coast & 2014 & 100 & 26 & 74 & 26.3 \\
\hline Varengeville & M. edulis & English Channel & Coast & 2014 & 170 & 92 & 78 & 54.1 \\
\hline Antifer - digue & M. edulis & English Channel & Coast & 2014 & 170 & 52 & 118 & 30.7 \\
\hline Cap de la Hève & M. edulis & English Channel & Estuary & 2014 & 320 & 85 & 235 & 26.5 \\
\hline Ouistreham & M. edulis & English Channel & River & 2014 & 150 & 48 & 102 & 31.9 \\
\hline Villerville & M. edulis & English Channel & Estuary & 2014 & 250 & 94 & 156 & 37.6 \\
\hline Port en Bessin & M. edulis & English Channel & Coast & 2014 & 250 & 85 & 165 & 34.2 \\
\hline Bdv Grandcamp ouest & M. edulis & English Channel & River & 2014 & 100 & 30 & 70 & 30.0 \\
\hline Le Moulard & M. edulis & English Channel & Coast & 2014 & 280 & 135 & 145 & 48.2 \\
\hline Grande rade de Cherbourg & M. edulis & English Channel & Bay & 2014 & 190 & 48 & 142 & 25.3 \\
\hline Bréville & M. edulis & English Channel & Coast & 2014 & 190 & 40 & 150 & 21.1 \\
\hline Le Vivier sur mer & M. edulis & English Channel & Bay & 2014 & 120 & 31 & 89 & 25.8 \\
\hline La Gauthier & M. galloprovincialis & English Channel & River & 2014 & 160 & 46 & 114 & 28.8 \\
\hline Baie de la Fresnaye & M. edulis & English Channel & Bay & 2014 & 120 & 22 & 98 & 18.3 \\
\hline Pointe du Roselier & M. galloprovincialis & English Channel & Coast & 2014 & 90 & 26 & 64 & 28.9 \\
\hline Beg Nod & C. gigas & English Channel & Coast & 2014 & 180 & 43 & 137 & 23.9 \\
\hline St Michel en grève & M. edulis & English Channel & Coast & 2014 & 150 & 39 & 111 & 25.8 \\
\hline Pen al Lann & C. gigas & English Channel & Coast & 2014 & 170 & 60 & 110 & 35.5 \\
\hline Aber Benoît & C. gigas & English Channel & Coast & 2014 & 100 & 18 & 82 & 18.2 \\
\hline Le Passage (b) & C. gigas & Atlantic & Bay & 2014 & 230 & 83 & 147 & 36.1 \\
\hline Rossermeur & C. gigas & Atlantic & Bay & 2014 & 110 & 33 & 77 & 30.1 \\
\hline Persuel & C. gigas & Atlantic & Bay & 2014 & 170 & 50 & 120 & 29.3 \\
\hline Aulne rive droite & C. gigas & Atlantic & River & 2014 & 310 & 59 & 251 & 18.9 \\
\hline Pointe de Mousterlin & M. edulis & Atlantic & Coast & 2014 & 150 & 49 & 101 & 32.4 \\
\hline Riec sur Belon & C. gigas & Atlantic & River & 2014 & 200 & 89 & 111 & 44.3 \\
\hline La Jument & M. edulis & Atlantic & River & 2014 & 130 & 61 & 69 & 46.6 \\
\hline Beg er Vil & C. gigas & Atlantic & River & 2014 & 180 & 62 & 118 & 34.6 \\
\hline Le Guilvin & C. gigas & Atlantic & Bay & 2014 & 200 & 72 & 128 & 35.8 \\
\hline Roguedas & C. gigas & Atlantic & River & 2014 & 160 & 69 & 91 & 43.4 \\
\hline Pointe er Fosse & C. gigas & Atlantic & River & 2014 & 200 & 100 & 100 & 49.9 \\
\hline Pen Bé & M. edulis & Atlantic & Bay & 2014 & 130 & 53 & 77 & 40.8 \\
\hline Le Croisic & M. edulis & Atlantic & Coast & 2014 & 120 & 61 & 59 & 51.0 \\
\hline Pointe de Chemoulin & M. edulis & Atlantic & Estuary & 2014 & 200 & 92 & 108 & 46.1 \\
\hline Bourgneuf - Coupelasse & C. gigas & Atlantic & Bay & 2014 & 200 & 48 & 152 & 24.1 \\
\hline Noirmoutier - Gresse-loup & C. gigas & Atlantic & Bay & 2014 & 360 & 145 & 215 & 40.2 \\
\hline Talmont & C. gigas & Atlantic & River & 2014 & 280 & 87 & 193 & 30.9 \\
\hline Rivedoux & C. gigas & Atlantic & Coast & 2014 & 260 & 57 & 203 & 22.1 \\
\hline Baie de l'Aiguillon & C. gigas & Atlantic & Bay & 2014 & 350 & 108 & 242 & 30.8 \\
\hline Châtelaillon & C. gigas & Atlantic & Coast & 2014 & 200 & 32 & 168 & 16.0 \\
\hline Les Palles & C. gigas & Atlantic & River & 2014 & 220 & 82 & 138 & 37.1 \\
\hline Boyardville & C. gigas & Atlantic & Coast & 2014 & 350 & 111 & 239 & 31.8 \\
\hline Dagnas & C. gigas & Atlantic & Bay & 2014 & 240 & 69 & 171 & 28.8 \\
\hline La Mouclière & M. edulis & Atlantic & River & 2014 & 120 & 29 & 91 & 23.9 \\
\hline Mus de loup & C. gigas & Atlantic & River & 2014 & 200 & 65 & 135 & 32.6 \\
\hline Pontaillac & C. gigas & Atlantic & Estuary & 2014 & 310 & 55 & 255 & 17.8 \\
\hline Bonne Anse - Palmyre & C. gigas & Atlantic & Estuary & 2014 & 380 & 106 & 274 & 27.9 \\
\hline La Fosse & C. gigas & Atlantic & Estuary & 2014 & 350 & 48 & 302 & 13.6 \\
\hline Cap Ferret & C. gigas & Atlantic & Bay & 2014 & 250 & 51 & 199 & 20.5 \\
\hline Les Jacquets & C. gigas & Atlantic & Bay & 2014 & 340 & 87 & 253 & 25.6 \\
\hline Comprian & C. gigas & Atlantic & Bay & 2014 & 310 & 77 & 233 & 24.9 \\
\hline Capbreton ouest & M. edulis & Atlantic & River & 2014 & 210 & 89 & 121 & 42.3 \\
\hline Adour marégraphe & C. gigas & Atlantic & River & 2014 & 200 & 56 & 144 & 28.1 \\
\hline Ciboure - la Nivelle & C. gigas & Atlantic & River & 2014 & 260 & 57 & 203 & 21.9 \\
\hline Hendaye - Chingoudy 2 & C. gigas & Atlantic & River & 2014 & 200 & 70 & 130 & 34.8 \\
\hline Banyuls - Labo Arago & M. galloprovincialis & Mediterranean & Coast & 2014 & 110 & 20 & 90 & 18.1 \\
\hline Embouchure de l'Hérault & M. galloprovincialis & Mediterranean & River & 2014 & 140 & 61 & 79 & 43.4 \\
\hline Etang de Leucate & M. galloprovincialis & Mediterranean & Lagoon & 2014 & 70 & 25 & 45 & 35.8 \\
\hline Etang de Bages & M. galloprovincialis & Mediterranean & Lagoon & 2014 & 132 & 19 & 113 & 14.2 \\
\hline Thau 1 & M. galloprovincialis & Mediterranean & Lagoon & 2014 & 90 & 36 & 54 & 40.4 \\
\hline Thau 4 & M. galloprovincialis & Mediterranean & Lagoon & 2014 & 100 & 33 & 67 & 32.8 \\
\hline Etang du Prévost & M. galloprovincialis & Mediterranean & Lagoon & 2014 & 180 & 91 & 89 & 50.7 \\
\hline Saintes-Maries-de-la-Mer & M. galloprovincialis & Mediterranean & Coast & 2014 & 160 & 57 & 103 & 35.4 \\
\hline Pointe St Gervais & M. galloprovincialis & Mediterranean & Bay & 2014 & 260 & 65 & 195 & 24.9 \\
\hline Anse de Carteau 2 & M. galloprovincialis & Mediterranean & Bay & 2014 & 170 & 51 & 119 & 29.9 \\
\hline Cap Couronne & M. galloprovincialis & Mediterranean & Coast & 2014 & 290 & 77 & 213 & 26.7 \\
\hline Pomègues Est & M. galloprovincialis & Mediterranean & Coast & 2014 & 260 & 112 & 148 & 43.2 \\
\hline Toulon - Lazaret & M. galloprovincialis & Mediterranean & Bay & 2014 & 670 & 132 & 538 & 19.7 \\
\hline Golfe de la Napoule & M. galloprovincialis & Mediterranean & Coast & 2014 & 140 & 41 & 99 & 29.3 \\
\hline Etang de Diana & M. galloprovincialis & Mediterranean & Lagoon & 2014 & 80 & 18 & 62 & 22.9 \\
\hline Sant'Amanza & M. galloprovincialis & Mediterranean & Bay & 2014 & 110 & 49 & 61 & 44.1 \\
\hline Ajaccio - Pte de Parata & M. galloprovincialis & Mediterranean & Coast & 2014 & 150 & 41 & 109 & 27.6 \\
\hline Pointe J'ai Fouillé & I.alatus & Caribbean & Coast & 2006 & 70 & 9 & 61 & 13.1 \\
\hline Le Marin - La Duprey & I.alatus & Caribbean & Coast & 2006 & 60 & 17 & 43 & 27.5 \\
\hline
\end{tabular}




\begin{tabular}{|c|c|c|c|c|c|c|c|c|}
\hline Site & Specie & $\begin{array}{c}\text { Sea/Ocean } \\
\text { location }\end{array}$ & Ecosystem & Year & $\begin{array}{c}\text { HgT } \\
\left(\mu \mathrm{g} \cdot \mathrm{kg}^{-1} \mathrm{dw}\right)\end{array}$ & $\begin{array}{c}\text { MeHg } \\
\left(\mu \mathrm{g} . \mathrm{kg}^{-1} \mathrm{dw}\right)\end{array}$ & $\begin{array}{c}\text { IHg } \\
\left(\mu \mathrm{g} . \mathrm{kg}^{-1} \mathrm{dw}\right)\end{array}$ & $\begin{array}{c}\text { ratio } \\
(\%)\end{array}$ \\
\hline Vaucottes & M. edulis & English Channel & Coast & 1989 & 290 & 46 & 244 & 15.9 \\
\hline Vaucottes & M. edulis & English Channel & Coast & 1993 & 640 & 109 & 531 & 17.1 \\
\hline Vaucottes & M. edulis & English Channel & Coast & 1997 & 630 & 82 & 548 & 12.9 \\
\hline Vaucottes & M. edulis & English Channel & Coast & 1998 & 660 & 90 & 570 & 13.6 \\
\hline Vaucottes & M. edulis & English Channel & Coast & 2003 & 200 & 56 & 144 & 28.0 \\
\hline Vaucottes & M. edulis & English Channel & Coast & 2005 & 360 & 77 & 283 & 21.3 \\
\hline Villerville & M. edulis & English Channel & Coast & 1987 & 170 & 79 & 91 & 46.6 \\
\hline Villerville & M. edulis & English Channel & Coast & 1990 & 220 & 66 & 154 & 30.1 \\
\hline Villerville & M. edulis & English Channel & Coast & 1993 & 210 & 63 & 147 & 30.2 \\
\hline Villerville & M. edulis & English Channel & Coast & 1996 & 250 & 77 & 173 & 30.9 \\
\hline Villerville & M. edulis & English Channel & Coast & 1999 & 170 & 63 & 107 & 37.3 \\
\hline Villerville & M. edulis & English Channel & Coast & 2002 & 260 & 85 & 175 & 32.6 \\
\hline Villerville & M. edulis & English Channel & Coast & 2005 & 190 & 71 & 119 & 37.2 \\
\hline Villerville & M. edulis & English Channel & Coast & 2008 & 240 & 74 & 166 & 31.0 \\
\hline Villerville & M. edulis & English Channel & Coast & 2011 & 288 & 90 & 198 & 31.2 \\
\hline Villerville & M. edulis & English Channel & Coast & 2014 & 250 & 94 & 156 & 37.6 \\
\hline Baie de la Fresnaye & M. edulis & English Channel & Bay & 1987 & 70 & 22 & 48 & 31.7 \\
\hline Baie de la Fresnaye & M. edulis & English Channel & Bay & 1990 & 80 & 24 & 56 & 30.6 \\
\hline Baie de la Fresnaye & M. edulis & English Channel & Bay & 1993 & 100 & 26 & 74 & 25.5 \\
\hline Baie de la Fresnaye & M. edulis & English Channel & Bay & 1996 & 50 & 17 & 33 & 34.2 \\
\hline Baie de la Fresnaye & M. edulis & English Channel & Bay & 1999 & 70 & 25 & 45 & 36.3 \\
\hline Baie de la Fresnaye & M. edulis & English Channel & Bay & 2002 & 60 & 23 & 37 & 38.4 \\
\hline Baie de la Fresnaye & M. edulis & English Channel & Bay & 2005 & 90 & 22 & 68 & 24.6 \\
\hline Baie de la Fresnaye & M. edulis & English Channel & Bay & 2008 & 70 & 23 & 47 & 32.9 \\
\hline Baie de la Fresnaye & M. edulis & English Channel & Bay & 2011 & 83 & 25 & 58 & 30.6 \\
\hline Baie de la Fresnaye & M. edulis & English Channel & Bay & 2014 & 120 & 22 & 98 & 18.3 \\
\hline Pointe de Chemoulin & M. edulis & Atlantic & Estuary & 1987 & 210 & 88 & 122 & 42.0 \\
\hline Pointe de Chemoulin & M. edulis & Atlantic & Estuary & 1990 & 220 & 89 & 131 & 40.5 \\
\hline Pointe de Chemoulin & M. edulis & Atlantic & Estuary & 1993 & 130 & 49 & 81 & 37.3 \\
\hline Pointe de Chemoulin & M. edulis & Atlantic & Estuary & 1996 & 160 & 64 & 96 & 40.2 \\
\hline Pointe de Chemoulin & M. edulis & Atlantic & Estuary & 1999 & 170 & 71 & 99 & 41.7 \\
\hline Pointe de Chemoulin & M. edulis & Atlantic & Estuary & 2002 & 180 & 70 & 110 & 38.8 \\
\hline Pointe de Chemoulin & M. edulis & Atlantic & Estuary & 2005 & 170 & 74 & 96 & 43.8 \\
\hline Pointe de Chemoulin & M. edulis & Atlantic & Estuary & 2008 & 170 & 76 & 94 & 44.9 \\
\hline Pointe de Chemoulin & M. edulis & Atlantic & Estuary & 2011 & 166 & 57 & 109 & 34.2 \\
\hline Pointe de Chemoulin & M. edulis & Atlantic & Estuary & 2014 & 200 & 92 & 108 & 46.1 \\
\hline Bourgneuf - Coupelasse & C. gigas & Atlantic & Bay & 1987 & 250 & 57 & 193 & 22.9 \\
\hline Bourgneuf - Coupelasse & C. gigas & Atlantic & Bay & 1990 & 190 & 53 & 137 & 28.1 \\
\hline Bourgneuf - Coupelasse & C. gigas & Atlantic & Bay & 1993 & 240 & 55 & 185 & 22.8 \\
\hline Bourgneuf - Coupelasse & C. gigas & Atlantic & Bay & 1996 & 200 & 47 & 153 & 23.5 \\
\hline Bourgneuf - Coupelasse & C. gigas & Atlantic & Bay & 1999 & 250 & 37 & 213 & 14.6 \\
\hline Bourgneuf - Coupelasse & C. gigas & Atlantic & Bay & 2002 & 330 & 98 & 232 & 29.6 \\
\hline Bourgneuf - Coupelasse & C. gigas & Atlantic & Bay & 2005 & 160 & 55 & 105 & 34.4 \\
\hline Bourgneuf - Coupelasse & C. gigas & Atlantic & Bay & 2008 & 190 & 53 & 137 & 28.1 \\
\hline Bourgneuf - Coupelasse & C. gigas & Atlantic & Bay & 2011 & 187 & 39 & 148 & 20.8 \\
\hline Bourgneuf - Coupelasse & C. gigas & Atlantic & Bay & 2014 & 200 & 48 & 152 & 24.1 \\
\hline La Fosse & C. gigas & Atlantic & Estuary & 1987 & 370 & 68 & 302 & 18.4 \\
\hline La Fosse & C. gigas & Atlantic & Estuary & 1990 & 220 & 49 & 171 & 22.3 \\
\hline La Fosse & C. gigas & Atlantic & Estuary & 1993 & 350 & 66 & 284 & 18.8 \\
\hline La Fosse & C. gigas & Atlantic & Estuary & 1996 & 270 & 56 & 214 & 20.6 \\
\hline La Fosse & C. gigas & Atlantic & Estuary & 1999 & 280 & 35 & 245 & 12.4 \\
\hline La Fosse & C. gigas & Atlantic & Estuary & 2002 & 230 & 41 & 189 & 17.7 \\
\hline La Fosse & C. gigas & Atlantic & Estuary & 2005 & 120 & 22 & 98 & 18.5 \\
\hline La Fosse & C. gigas & Atlantic & Estuary & 2008 & 290 & 32 & 258 & 11.0 \\
\hline La Fosse & C. gigas & Atlantic & Estuary & 2011 & 234 & 36 & 198 & 15.3 \\
\hline La Fosse & C. gigas & Atlantic & Estuary & 2014 & 350 & 48 & 302 & 13.6 \\
\hline Cap Ferret & C. gigas & Atlantic & Bay & 1987 & 330 & 81 & 249 & 24.5 \\
\hline Cap Ferret & C. gigas & Atlantic & Bay & 1990 & 240 & 49 & 191 & 20.3 \\
\hline Cap Ferret & C. gigas & Atlantic & Bay & 1993 & 200 & 26 & 174 & 12.9 \\
\hline Cap Ferret & C. gigas & Atlantic & Bay & 1996 & 230 & 47 & 183 & 20.6 \\
\hline Cap Ferret & C. gigas & Atlantic & Bay & 1999 & 320 & 51 & 269 & 15.9 \\
\hline Cap Ferret & C. gigas & Atlantic & Bay & 2002 & 160 & 42 & 118 & 26.1 \\
\hline Cap Ferret & C. gigas & Atlantic & Bay & 2005 & 230 & 46 & 184 & 19.8 \\
\hline Cap Ferret & C. gigas & Atlantic & Bay & 2008 & 100 & 30 & 70 & 30.2 \\
\hline Cap Ferret & C. gigas & Atlantic & Bay & 2011 & 139 & 28 & 111 & 20.3 \\
\hline Cap Ferret & C. gigas & Atlantic & Bay & 2014 & 250 & 51 & 199 & 20.5 \\
\hline Thau 4 & M. galloprovincialis & Mediterranean & Lagoon & 1987 & 100 & 53 & 47 & 53.5 \\
\hline Thau 4 & M. galloprovincialis & Mediterranean & Lagoon & 1990 & 140 & 63 & 77 & 45.1 \\
\hline Thau 4 & M. galloprovincialis & Mediterranean & Lagoon & 1993 & 100 & 34 & 66 & 34.4 \\
\hline Thau 4 & M. galloprovincialis & Mediterranean & Lagoon & 1996 & 130 & 45 & 85 & 34.8 \\
\hline Thau 4 & M. galloprovincialis & Mediterranean & Lagoon & 1999 & 90 & 50 & 40 & 55.8 \\
\hline Thau 4 & M. galloprovincialis & Mediterranean & Lagoon & 2002 & 100 & 57 & 43 & 56.6 \\
\hline Thau 4 & M. galloprovincialis & Mediterranean & Lagoon & 2005 & 100 & 43 & 57 & 42.6 \\
\hline Thau 4 & M. galloprovincialis & Mediterranean & Lagoon & 2008 & 120 & 53 & 67 & 44.5 \\
\hline Thau 4 & M. galloprovincialis & Mediterranean & Lagoon & 2011 & 118 & 35 & 83 & 29.3 \\
\hline Thau 4 & M. galloprovincialis & Mediterranean & Lagoon & 2014 & 100 & 33 & 67 & 32.8 \\
\hline
\end{tabular}




\begin{tabular}{|c|c|c|c|c|c|c|c|c|}
\hline Cap Couronne & M. galloprovincialis & Mediterranean & Coast & 1987 & 390 & 119 & 271 & 30.5 \\
\hline Cap Couronne & M. galloprovincialis & Mediterranean & Coast & 1990 & 160 & 45 & 115 & 28.2 \\
\hline Cap Couronne & M. galloprovincialis & Mediterranean & Coast & 1993 & 280 & 70 & 210 & 24.8 \\
\hline Cap Couronne & M. galloprovincialis & Mediterranean & Coast & 1999 & 300 & 55 & 245 & 18.2 \\
\hline Cap Couronne & M. galloprovincialis & Mediterranean & Coast & 2002 & 220 & 79 & 141 & 36.0 \\
\hline Cap Couronne & M. galloprovincialis & Mediterranean & Coast & 2005 & 270 & 85 & 185 & 31.6 \\
\hline Cap Couronne & M. galloprovincialis & Mediterranean & Coast & 2008 & 200 & 55 & 145 & 27.4 \\
\hline Cap Couronne & M. galloprovincialis & Mediterranean & Coast & 2011 & 295 & 74 & 221 & 25.2 \\
\hline Cap Couronne & M. galloprovincialis & Mediterranean & Coast & 2014 & 290 & 77 & 213 & 26.7 \\
\hline Toulon - Lazaret & M. galloprovincialis & Mediterranean & Bay & 1987 & 370 & 86 & 284 & 23.3 \\
\hline Toulon - Lazaret & M. galloprovincialis & Mediterranean & Bay & 1990 & 440 & 50 & 390 & 11.4 \\
\hline Toulon - Lazaret & M. galloprovincialis & Mediterranean & Bay & 1993 & 230 & 38 & 192 & 16.3 \\
\hline Toulon - Lazaret & M. galloprovincialis & Mediterranean & Bay & 1996 & 320 & 43 & 277 & 13.6 \\
\hline Toulon - Lazaret & M. galloprovincialis & Mediterranean & Bay & 1999 & 500 & 105 & 395 & 21.1 \\
\hline Toulon - Lazaret & M. galloprovincialis & Mediterranean & Bay & 2002 & 530 & 114 & 416 & 21.4 \\
\hline Toulon - Lazaret & M. galloprovincialis & Mediterranean & Bay & 2005 & 540 & 172 & 368 & 31.8 \\
\hline Toulon - Lazaret & M. galloprovincialis & Mediterranean & Bay & 2008 & 700 & 171 & 529 & 24.5 \\
\hline Toulon - Lazaret & M. galloprovincialis & Mediterranean & Bay & 2011 & 520 & 68 & 452 & 13.2 \\
\hline Toulon - Lazaret & M. galloprovincialis & Mediterranean & Bay & 2014 & 670 & 132 & 538 & 19.7 \\
\hline Golfe de la Napoule & M. galloprovincialis & Mediterranean & Coast & 1987 & 250 & 69 & 181 & 27.5 \\
\hline Golfe de la Napoule & M. galloprovincialis & Mediterranean & Coast & 1990 & 160 & 54 & 106 & 33.9 \\
\hline Golfe de la Napoule & M. galloprovincialis & Mediterranean & Coast & 1993 & 270 & 71 & 199 & 26.2 \\
\hline Golfe de la Napoule & M. galloprovincialis & Mediterranean & Coast & 1999 & 210 & 74 & 136 & 35.2 \\
\hline Golfe de la Napoule & M. galloprovincialis & Mediterranean & Coast & 2002 & 130 & 45 & 85 & 35.0 \\
\hline Golfe de la Napoule & M. galloprovincialis & Mediterranean & Coast & 2005 & 160 & 40 & 120 & 25.1 \\
\hline Golfe de la Napoule & M. galloprovincialis & Mediterranean & Coast & 2008 & 140 & 24 & 116 & 17.4 \\
\hline Golfe de la Napoule & M. galloprovincialis & Mediterranean & Coast & 2011 & 121 & 30 & 91 & 24.5 \\
\hline Golfe de la Napoule & M. galloprovincialis & Mediterranean & Coast & 2014 & 140 & 41 & 99 & 29.3 \\
\hline
\end{tabular}

